\title{
FAMILY COMMUNICATION ON SINGLE MOTHER FAMILIES
}

\author{
Lucy Pujasari Supratman \\ Communication Department, \\ Faculty of Communication and Business \\ Universitas Telkom, Bandung, Indonesia \\ Jl. Telekomunikasi No. 01, Terusan Buah Batu, Sukapura, Dayeuhkolot, \\ Bandung, Jawa Barat 40257. Telp. (022) 7564108 \\ Email : lucysupratman@telkomuniversity.ac.id
}

\begin{abstract}
The filing of divorce by women is increasingly today. There are at least 553 divorce cases registered to Bandung Religious Court in 2017. Most dominate divorce applicants were proposed by women. The purpose of this study was to describe the form of family communication done by single mothers to their teenagers as a single parent. The methods used in this research is qualitative with the analytical case study approach. The researcher interviewed five single mothers who lived in Bandung. The result was the interpersonal communications on all informants were divided into coercive and democratic communication. The democratic communication is the most effective communication form to build a strong bond with the teenagers in a new single family. The contribution of this research is providing a new model of interpersonal coercive communication.
\end{abstract}

Keywords: Interpersonal Communication, Single Mother, Divorce.

\begin{abstract}
Abstrak
Pengajuan perceraian oleh perempuan semakin hari semakin banyak. Sedikitnya ada 553 kasus perceraian terdaftar di Bandung untuk mencapai pengadilan agama di 2017. Pengajuan perceraian tersebut banyak didominasi oleh perempuan. Tujuan penelitian ini untuk menggambarkan bentuk komunikasi yang dilakukan oleh orang tua tunggal kepada anak-anak mereka setelah perceraian. Metode yang digunakan dalam penelitian ini adalah kualitatif dengan pendekatan studi kasus. Narasumber dalam studi ini ada lima ibu tunggal yang tinggal di Bandung. Hasil dari studi ini adalah ada dua komunikasi interpersonal pada semua informan, yaitu komunikasi koersif dan demokratis. Komunikasi demokrasi adalah bentuk komunikasi yang baik dan efektif. Selain itu komunikasi tersebut adalah yang paling kuat dan kokoh untuk membangun ikatan antara orang tua tunggal dan anak-anak mereka dalam sebuah situasi keluarga yang baru. Kontribusi penelitian ini berupa model baru mengenai komunikasi koersif antarpribadi.
\end{abstract}

Kunci: komunikasi interpersonal, ibu tunggal, perceraian.

\section{Introduction}

Bandung city occupies the third highest divorce position in Indonesia. From the data obtained at Bandung Religious Court, 5890 cases were handled by courts in 2016. The highest reason of 70 percent was dominated by economic factors (5205 cases). Bandung City Religious Court (Jalaludin, 2017) revealed the total numbers of 5,890 divorce cases were filed by women to husbands. There were 553 divorce cases were mostly proposed by women during January 2017 in Bandung Religious Court.

The filing of divorce by women has not become a sacred thing nowadays. Women today are daring to file for a divorce (Supratman, 2017). In interviews with informants, women must have the courageous in deciding their lives and gaining equality in self-actualization. Some of them have well-financially and are independence to survive without relying on their husbands. However, inequality in the 
appreciation given by the husband made them feel to be the subordinate in the family. They are seen to be the objects in marriage rather than being subjects with equal rights. They feel that they do not get equal justice which benefits both sides.

Most informants said that they are always at a low point in the function of marriage, even though their economic level is higher than their counterparts. They are also the ones who support the family economy without getting a reward for their efforts to improve the standard of family life. Similarly, in domestic duties, women feel burdened with doing their homework without being helped by their spouses during their marriage. Suciati (2013) stated that the divorce reason happened in Indonesia due to the couples who are no longer upholding openness and trust. Beebe (1996) said that it is not a good marriage if any member of persons cannot live cooperatively with one another over time in common living space.

A family where the spouses avoid doing cooperative family tasks has a great tendency to be separated. Their ex-husband order and ask the wives to do domestic obligation alone, rather that work together. Devito (2004) explained that having the clear role play among family members will tighten family communication relationship and emit internal conflict.

These divorce reasons should be communicated in an appropriate way to the young teenagers (their children). The way of communicating with a single mother will shape the new family atmosphere. They shall be told that the divorce reason will not be a primary focus again to be discussed after the divorce or the opposite of that. The divorce reason becomes the shield to blame their father. When it comes to the second option, the communication way of a single mother will affect to reject the father existence in a single family. It means the divorce intention still cannot be saved by both parties.

Family communication of single mother is shaped with a different condition. The single mothers need to change their children frame of mind about the divorce decision. They try to influence them through verbal and nonverbal communication. The goal of using this interpersonal communication between single mothers and their children is to make the young teenagers accept the divorce without blaming themselves or anyone else. Also, it can make the stronger bond of the broken family relationship between single mother and the teenagers after the divorce conflicts. Teenagers from divorce family have been documented in the literature that they are subject to cognitive, behavioral, and affective problems within the first year of separation/divorce (Anderson, 1994). It is still in Anderson research, the majority of children of all age groups was reported to have significant psychosocial problems following parental divorce, and these problems varied according to the child's age. Youngest children were whiny, fearful, and aggressive, exhibited regressive behavior, and were possessive. Preschool children did not appear to understand the divorce and blamed themselves for their parents' separation. School-aged children experienced mixed feelings of sadness, anxiety, and anger. Many of these children had conflicts of divided loyalty and wished that their parents would reconcile. 
Seeing the phenomenon of the increasingly changing position of women who switched positions from women who dare to sue the divorce to the religious court, it has become the interesting subject of the family communication to examine their interpersonal communication in a new family form. Lichtman (2013) said that the cooperation between parents and their young teenagers had been the subject of intensive research in recent decades. This research focused on the form of single mother family communication to their teenagers after the divorce. This issue is very useful to be discussed as it will contribute to the development of family communication modeling. Besides that, some forms of communication applied by a single mother are an ideal form of communication to be used by other single mothers. The purpose of this study was to describe the form of family communication done by single mothers to their teenagers as a single parent.

\section{Research Method}

I use a qualitative explanatory case study in describing the type of communication pattern of a single mother after the divorce. Based on Yin (2010), the approach of elaborating the uniqueness of a case needs to use an explanatory qualitative study. The research question on 'How' and 'Why' related to the participant observation in gaining the field data from the informant. There are ten single mothers who are involved in this research. They asked the divorce plea to the court to get the divorce agreement and the interpersonal communication made by them in daily life. I gained the informants through purposive sampling with the characteristics
(1) Single mothers who have been through the divorce for 2 years or more; (2) Single mothers with the 'divorced' status; (3) Single mothers who have children in teenagers ages; (4) Single mothers with good financially record; (5) Well-educated single mothers.

The research object is the interpersonal communication pattern of single mothers. These patterns should be analyzed in a purpose to fulfill the ideal of communication pattern for single mothers. The technical data analysis is observation, in-depth interview and observation. After the data obtained, I did four steps triangulation data. I interviewed and did the observation to five single mothers for one year occasion. After the interview transcripts and field notes collected, I reduce all data through categorization. In reducing the data, I categorized it based on construct on a second degree, member checking, and data triangulation.

\section{Result of Research and Discussion}

Single mothers in this study have proposed their divorce by their plea to the religious court. The reasons for having the divorce plea are not primarily due to economic or other general issues (such as the involvement of the third party and so on). These ten informants of single mothers submitted their divorce to get the respect. This finding has been a novelty to the fact that the main reason for having the divorce is the lack of self-acceptance from both parties. The single mothers decided not to marry for wanting the freedom to live and raise their teenagers as their parenting way. They feel free of the insolence and injustice with the first initiator to propose the divorce. 
Tong (2009) said that it is women who determine whether the human species continues and whether there is life or no life. Women must guard and celebrate this lifegiving power, for, without it, men will have even less respect and use for women than they have now. Hence, they are better off alone and feel happier in living their own lives. They dare to face independent life to raise children. Single mothers dare to decide their choice of life in achieving happiness and pursuing higher education to get more respect. Chandler (2010), talked about the emerging effort of a single parent in pursuing the education. The participants sought graduate degrees as a means to improve the standard of living for themselves and their families.

All informants in this research put education in the first rank to get a better wage. Having the experiences of being single mothers has opened their mind frame to increase the quality of life as the breadwinner. Similar research has done by Nelson (2009) that how low single mothers keep providing themselves with a good education. Even they have to struggle with the persistence in studying from the first year to four-year in the college.

Post-divorce communication is the most difficult things to do for a single parent to fix the interpersonal communication. All informants told about the difficulties of telling the divorce reason to their young teenagers. Many of the teenagers required more time to adjust their mother decision to be the first divorce plea to the religious court. They could not understand about their mother's condition who are suffered by the unfair and unappreciated. This is where the interpersonal communication of single mothers takes an important role to approach the young teenagers and makes them understand the divorce reason.

The form of communication which is performed by single mother and female adolescents in communicating each other, shaped in a variety of forms. There are single mothers who decided not to get married but being coercive for not allowing the teenagers to meet her father. This type of single mother is still feeling hurt (not willing to reconcile) to her ex-husbands. They already feel able regarding economic / well established too. However, the young teenagers are less comfortable at home and need more time to adapt to the environment of new family form. There are also single mothers who apply the democratic interpersonal communication by involving their children to make a decision. In democratic interpersonal communication, the single mothers dismiss the selfishness feeling and prioritize the psychological development of their children. They keep building a conducive single family atmosphere to maintain the loving bond of single mothers with their son/daughter.

Single mother communication with the teenagers runs intensively. They communicate more in the form of mutual emotional communication due to the sex similarity. The teenagers get positive feedback in the presence of single mothers who listen attentively to the outpouring of teenager's stories. Listening which is done by single mothers can be interpreted as an activity that manifested in the process of sending back to the speaker about our thoughts, meaning of the contents and feelings of the speaker. 
The interview with a single mother (first informant) told that the interpersonal communication shaped by the willing to share each other feeling. They can chat freely every day. Single mother melted the thick atmosphere by asking the condition first to the children. The chat topics are friends, school, to teenage romance problems. The place they chatted was spent in the dining room, so the interpersonal communication will not be too formal. The dining table full of food and beverages is placed where every chat started easily. While they do the chatting, they can enjoy the available food. When the atmosphere is created comfortable and relaxed, the communication message will be easy to be delivered by single mothers. They can dig each other problems and share information together.

"We chat every day. The chat topics are about school, event competitions, extra lessons, we chat all stuff. I'm the one who invited my children first to have a chat; I listen to their stories. The dining table is the most favorite place to chat while having food."

This democratic communication formed by a single mother will always open good conversational question. The single mother's question mostly starts with 'how. The role of a single mother in the chat is as a listener, though sometimes they come to provide solutions through the thought of a wise mother. Single mother communication and female teenager build a strong emotional relationship to look for the problem-solving. Their communication uses a lot of affective rather than cognitive. But, it becomes a strong bond between single mothers and their female teenagers. Based on the interview session, the single mother will continue to think of the solution of family problems. They have to combine their roles as a mother and a father on one occasion. Once they face the problem, the single mother needs to use their masculine thought to get the solutions.

"I shall speak to the children, if there are little things to be discussed, just tell me... we'll figure out the way together. I like to say to the kids, pray me always with good health so our food canteen will have a lot of customers."

Second informant has become the initiator of communicator to melt the communication between her male teenagers. She communicated through patience. She patiently listened to the anger of their sons who blamed second informant and her husband for the state of the divorce. The second informant is very silent. She rarely speaks unimportantly very often. For some time, this form of silent communication makes the children realize their selfishness. She was relieved when she could get the children to start listening to the reason for divorce after a few minutes of silent communication.

"I was very quiet at home after the divorce with the children father. The kids blamed me of the divorce, but I never respond it. I just let them stand until they are content to blame me as the reason of splitting. For a long time they think why I keep silent, then in one moment they finally ask me. I ask them when is their free time to listen to my story without being paused by their anger, then they give me the spare time. I give a long explanation if their father do not want to commit to our marriage again, their father has another woman."

The patience of the second informant's to find a suitable time to dampen the emotions of children to speak from heart to heart with children addressed with nonverbal communication. The second informant rubs male teenager backs after allowing the fourth informant to speak without the emotional state. She also gives a discourse on how a man should be in a family. According to her, a father role is to protect the family, while children and 
wife should be protected. Reinforcement communicated by single mothers and male teenagers have refreshed the rigidity of relationships to make self-disclosure easier. Communication exchange becomes more balanced because each party has the same interests.

"Instead of getting angry with the kids who blame me for this divorce, I was just listening to them. I am often crying in the room alone or crying while praying. It's hurt me. I search for a positive runaway to do Qur'an recital, night praying, do the Sunnah fasting Monday and Thursday. Alhamdulillah it turns out my endeavor to bring the positive results, children accept my decision to divorce, they even give more attention to me."

The interpersonal communication of the third informant is precisely by giving full trust to their children. After the divorce, the male teenager of the third informant became a frequent hooker in school and an active smoker. In the beginning, the third informant did not believe the report about her son who likes to play truant from his school. She still trusts her son without any suspicious thought. Her children always go to school every morning and come home at noon. However, some neighbors keep reporting that the children didn't go to school. He played to his friend house to have smokes together. Once again, she denied that her son could not smoke and play truant after her son confesses by his own.

"I get the information about my play truant son on his final report at second grade. His teacher said that my son often skipped the classes. I do not believe; I do not know why I do not believe my son did the play truant. Some neighbors have also been reported about my son who smoked with his friends. I talked about my neighbor's report and his school teacher; I said I don't believe every single word they said about my son. I believe he's a good boy. Suddenly, he surprised me with his confession, he cried and apologized to me, whether what people said are true. He asked me, why I should be so much trust in him, well its definitely because I love him more than anything. Since his confession, we are so much closer each other until now. "
The message management (trust) communicated by the single mother (third informant) to her son has resulted in positive interaction. Her son becomes honest and can manage the conversation with good interaction. Honesty in interacting makes the third informant son becomes more obedient to his mother's wishes. Her son did not want to waste her mother's confidence anymore. The third informant understands her son's bad behavior is the form of seeking the attention of her. The third informant realized the time she spent she had been working had reduced the time they communicated at home. Now, the son of the third informant has begun to accept her mother's busyness. It is because she works with the orientation of fulfilling the needs of her son and as a responsible single mother. Nevertheless, they mostly do the communication process by using nonverbal communication interaction.

Democratic interpersonal communication means to have a happiness communication in a family. It is a communication form to improve the relationship with all family members. Wahlroos (1976) told in her book that the great happiness and the deepest satisfaction in life, the most profound inner peace all come from being a member of a loving family. Even the family is getting divorced or separated; the family member will keep learning how to create a harmonious condition between the single parents and the children in a democratic communication.

Some informants (single mothers) use democratic interpersonal communication to convey positive messages to their children. The figure beyond describes the democratic communication in verbally form. 


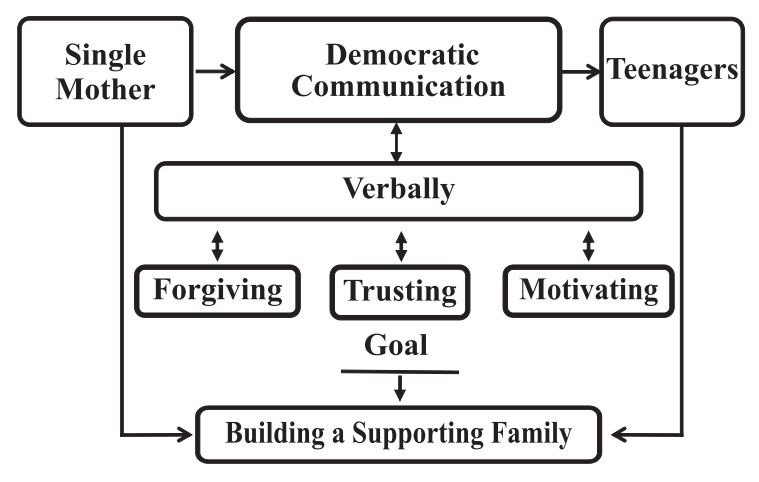

Picture 1.

Democratic Interpersonal Communication Source: Research Data (2017)

The coercive of interpersonal communication to second informants occurs when their female teenager see their mothers cry instantly. Crying for women is an expression of sadness over the pain. Single mother cried because of the injustice from their husband. This second informant has a long desire to divorce. After their children grow into female teenager, this single mother was daring to ask for a divorce. Single mother communicate her feeling firmly of expressing her distress. Moreover, their children finally forced to hate their father because they have known the truth of her mother tortured feelings.

"I've cried in burst because I cannot hold this tortured feeling, the children are deliberately see me crying. I express my willing to have divorce to the children, I said to the children... please I cannot take this any longer.."

In the fourth informant case, she still stays with her ex-husband until the court has legalized their divorce letter. But, they avoid each other's conversations and stares during the divorce process. After the letter of divorce issued by the religious court, the fourth informant left the house. She asked her daughter to come live together with her. The informant demands her daughter not to make any contact with her father. The heartache has made the informant difficult to forgive her exhusband. Bad stories about the ex-husband are told by the informant to her daughter.

The fourth informant continues to demand her children by staying their father away. Their father cannot provide them a proper life. Otherwise, the informant can give proper education, food, and a house to stay. She compared the life between following their father with no future at all or following her. She told the children that their father is not a man with pride and remind their lucky existence if they prefer to live with her. The words like being ungrateful of having a husband like he has made the children want to protect her mother from her father.

"We break the fast at the street food stall. I pointed my finger at a man who sleeps on the streets. I spoke to them; you are my sons. Don't you guys give up on the situation...Don't be like your father who abandoned us... unresponsible man. Abandoning his own family and away to support other people. I said to the kids, I always here for them. We can eat well, afford to pay for school, sleep on the mattress. You will not get those if you go with him."

The communication between single mother and single mother (fifth informant) with a male adolescent in interpersonal communication encourages the coercive process of refusing their father existence. Single mother communicates in a firmness tone voice. The firmness forced teenagers mind to reject him as an abandoned father. The fifth informants cannot often hold back her tears when telling her feelings before the divorce. This honest statement inspires the teenagers to protect his mother over their father's ill-treatment. This single mother becomes part of coercive interpersonal communication that placed 
negative experiences become the important message in a communication process. The fifth informant continues to support her children successfully by being grateful for having her as their loveable mother.

"I was left without living by my husband, so I propose the divorce. I reassure the children that even though they don't have father's role, I still love them and responsible for their life. "

Coercive communication which applied by these informants has reframed negative atmosphere in the family. The way of labeling their father as irresponsible and abandoned man reframed teenagers stress to cope with parents problem. The situation demands the teenagers in a difficult situation of engaging the parent's quarrel again.

Besides that, the informant's nonverbal interpersonal communication support the type of verbal communication in democratic and coercive communicating. The emotional attach expressed significantly in listening gesture, crying, patience and hugging to interpret democratic communication. While the insisting of facial expression, forcing gesture and firmness tone to strengthen the single mother dominance meaning in a coercive family. This is the table of nonverbal interpersonal communication:

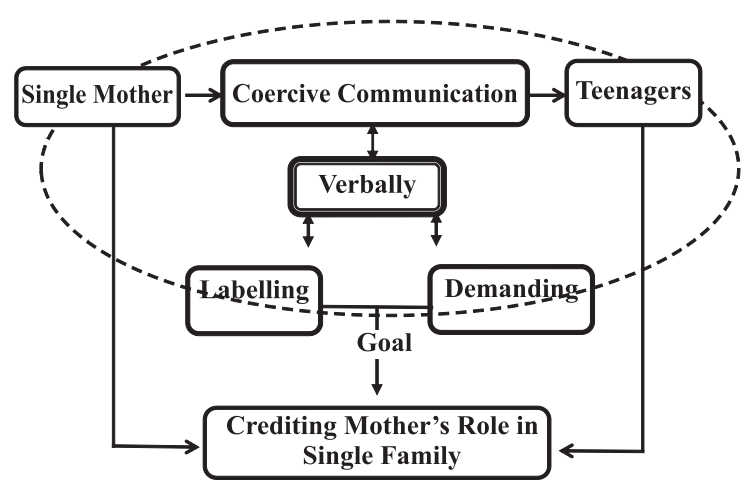

Picture 2.

Coercive Interpersonal Communication Source: Researcher Data (2017)
Table 1

Nonverbal Interpersonal Communication of Single Mothers

\begin{tabular}{ccc}
\hline $\begin{array}{c}\text { Nonverbal } \\
\text { Communication }\end{array}$ & $\begin{array}{c}\text { Single Mother } \\
\text { Expression }\end{array}$ & $\begin{array}{c}\text { Type of } \\
\text { Interpersonal } \\
\text { Communication }\end{array}$ \\
\hline $\begin{array}{c}\text { Facial } \\
\text { Expression } \\
\text { Gesture }\end{array}$ & Insisting & Coercive \\
Gesture & Forcing & Coercive \\
$\begin{array}{c}\text { Emotion } \\
\text { (kinesics) }\end{array}$ & Crying & Democratic \\
$\begin{array}{c}\text { Emotion } \\
\text { (kinesics) }\end{array}$ & Patience & Democratic \\
Haptics & Hugging & Democratic \\
Paralanguage & Firmness & Coercive \\
\hline
\end{tabular}

Source : Researcher Data (2017)

Nonverbal communication has a great portion of everyday interaction. As West (2006) said that nonverbal communication holds $65 \%$ portion of daily human communication rather than verbal communication with $35 \%$ portion. Budyatna (2014) explained the function of nonverbal communication to be the individual emotional. It reflects on the behavior of a person. The behavior would be expressed on the kinesics (eye contact, facial expression, emotion, gesture, posture, haptic) and paralanguage (pitch, volume, rate, and quality). These single mothers use facial expression, gesture, emotion, haptic and paralanguage in a motherhood manner. Beebe (1996) explained that nonverbal cues are important not only when people initiate a relationship, but also as people maintain and develop a mature relationship with others.

The feedback of using these nonverbal communications is the empathy from the teenagers. But not all teenagers express the empathy feeling to help their mother overcome the burdens as a single parent. Some teenagers only give the sympathy and keep doing the distance with their father. These single 
mother often speaks in a firmness way and quite overprotected to the teenagers. Still, in Beebe (1996), all of us are more likely to use nonverbal cues to convey negative messages than to announce our dislike of something or someone explicitly. Therefore, this coercive communication cannot bond the intimate relation between the teenagers and their father. The bond reflects merely between the teenagers and their single mother.

Interpersonal communication on all informants in this study is divided into coercive and democratic interpersonal communication. Trenholm (2004) stated that effective interpersonal communication would be useful if there is a centralized work from central member in a communication family process. A single mother is a centralized work who actively communicates as the primary communicator in controlling the family member affective (single mother and her teenagers). The house atmosphere is controlled by the act of single-member toward the teenagers. A single mother with coercive interpersonal communication will make the house atmosphere rigid. Teenagers cannot express their want and feel free to her single mother. While single mother with democratic interpersonal communication have made the teenagers visionary and independent. They have a great struggle to overcome the barriers together as a new small family team (single mother and the teenagers).

Unlike the democratic interpersonal communication, coercive communication prioritizes the egocentric of a single mother couple after divorce. She is the only one who can decide every decision in her single family. While democratic communication is healthier for the single mother and teenagers.
The form of democratic communications can make the single mother getting more in touch with their teenagers. They become very close and appear the awareness to keep working together to make every decision for the family. Their maturity attitude acts by subordinating the egocentric side and putting forward a wise attitude have made teenagers accept the divorce parents decisions with the big soul. In fact, being a single parent is not as easy as it looks. It needs the support of a whole member family to make this new family form (single parent and the teenagers) harmonious.

\section{Conclusion}

The success of informant communicating interpersonally with their teenagers comes from single mother democratic communication form. Democratic communication should always be imposed on teenagers from divorced family through spirit full motivations. The purpose of democratic communication is to convince the teenagers that they still get the same affection form the single mother. The divorce will not be a traumatic experience if the single mother can apply democratic communication. Teenagers souls will continue to grow by the outpouring fill of affection. Single mothers can play two roles at once. The first role is as a loving mother and father role as a protector. The adaptation of their single mother's self-communication (self-way, the psychological term) gives a sample to the teenagers that single mothers can be the right role model of the problem at hand. The role of a single mother in communicating her view of the divorce reason come from various forms of communication; there are coercive and democratic. Out of two 
forms of communication, the democratic communication form is the ideal form of communication that can be applied by the singles to their teenagers.

Democratic communication is a form of communication where the single mother put herself closer to the teenagers with the purpose of explaining the life changes that they will be experienced in the future. Single mother explains openly and democratically about their mother's new status as a divorced lady in the public assessment. With good communication, the informants managed to get their teenagers to accept the divorce. The process of acceptance by informants to their teenagers does take a long time. It is not easy for them to face the dilemma of parental divorce. Single mother as a significant other continues to provide affection; good sample, spirit, and motivation as the primary role model for teenagers in facing the divorce. A sense of mutual love each other is the foundation to get good family communication.

\section{References}

Anderson, Beverly A. (1994). Single Parent Family Strength. A Dissertation at the University of Utah.

Beebe, Steve A, et al. (1996). Interpersonal Communication: Relating to Others. Massachusetts: Allyn and Bacon.

Budyatna, Muhammad dan Leila Mona Ganiem. (2014). Teori Komunikasi Antarpribadi. Jakarta: Kencana.

Chandler, Kelly Lynn. (2010). An Exploratory Study of the Experience of Single Mothers in Higher Education: A Project-Based upon An Independent Investigation. Northampton, Massachusetts, USA: A Theses at Smith College School for Social Work,
Devito, Joseph. A. (2004). The Interpersonal Communication Book. Boston: Pearson.

Devito, Joseph. A. (2013). The Interpersonal Communication Book, $13^{\text {th }}$ Edition. Boston: Pearson.

Lichtman, Tsfira Grebelsky. (2013). Parental Patterns of Cooperation in Parent-Child Interactions: The Relationship Between Nonverbal and Verbal Communication. Human Communication Research Journal. Volume 40, Issue 1 January 2014. Pages $1-29$.

Nelson, Geraldine Hayes. (2009). A Study of Single Mothers' Experience of Persistence at A Four-Year Public University. State University College, USA: A Dissertation at Kent.

Wahlroos, Sven. (1976). Family Communication. New York: Signet Books.

Suciati. (2013). Kohesivitas Suami Istri Dalam Mewujudkan Keharmonisan Rumah Tangga: Studi Kasus di Gunung Kidul Yogyakarta. Jurnal ASPIKOM. Vol 2, No 1.

Supratman, Lucy Pujasari. (2017). A Changing Paradigma of Interpersonal Communication in Divorce Family. SHS Web of Conferences. EDP Sciences.

Tong, Rosemarie. Feminist Thought. (2009). Universty of North Carolina, USA.

Trenholm, Sarah dan Arthur Jensen. (2004). Interpersonal Communication. New York: Oxford University Press.

West, Richard \& Lynn H. Turner. (2006). Understanding Interpersonal Communication: Making Choices in Changing Times. Thomson Learning, Inc: Belmont, USA.

Yin, Robert K. (2010). Studi Kasus: Desain dan Metode. PT Raja Grafindo Persada: Jakarta.

\section{Internet}

Akhmad Jalaluddin. Bandung City Religious Court. January 2017. www. pikiranrakyat. com. Accessed on November 18, 2017. 


\title{
BAHASA INDONESIA LEARNING COMMUNICATION BY USING COOPERATIVE MODEL APPROACH
}

\author{
Syaiful Rohim \\ Study Program of Communication Science University of Muhammadiyah \\ Prof.Dr. HAMKA Jakarta \\ Jl. Limau 2, Kramat Pela, Kebayoran Baru, Jakarta Selatan, 12130. \\ Telp. 08159349713, Email : syaiful_rohim@uhamka.ac.id
}

\begin{abstract}
The purpose of this research is to test the student's learning achievement in class VIII SMPN 1 Bayongbong by using interactional education communication strategy in learning Indonesia Language by using "cooperative learning $(C L)$ " model which is done by the teacher in class. "Cooperative learning" model is a learning model which emphasizes that every learning process, students are active in build their knowledge (student-centered). This research is using positivism paradigm with the quantitative approach as a method to measure how far the impact of the independent variable to dependent variable. This research takes two classes as a sample. One class as an experiment class consists of 36 students who are using the cooperative model in the teaching-learning process, and the other class consists of 34 students as a control class which is using conventional method. The experiment result shows that learning communication strategy by using cooperative learning model has significantly influenced the student's learning achievement. This thing is supported by the data that shows student's achievement in learning Indonesia Language is better than the student's achievement which is using conventional learning communication strategy. The contribution of this research is to provide information to educators about better strategies in learning the Indonesian Language for students.
\end{abstract}

Keywords: communication strategy, cooperative learning, quasi-experiment.

\begin{abstract}
Abstrak
Tujuan dari penelitian ini adalah untuk menguji prestasi belajar siswa di kelas VIII SMPN 1 Bayongbong dengan menggunakan strategi komunikasi pendidikan interaksional dalam pembelajaran Bahasa Indonesia melalui model "cooperative learning" yang dilakukan oleh guru di dalam kelas. Model "Cooperative Learning" adalah model pembelajaran yang menekankan bahwa setiap proses pembelajaran, siswa aktif membangun pengetahuan mereka sendiri (berpusatpadasiswa). Penelitian ini menggunakan paradigma positivism dengan pendekatan kuantitatif sebagai suatu metode untuk mengukur sejauh mana dampak variable independen dan variable dependen. Penelitian ini mengambil sampel dua kelas. Satu kelas sebagai eksperimen kelas terdiri dari 36 siswa yang menggunakan model cooperative dalam proses belajar mengajar dan kelas lainnya terdiridari 34 siswa sebagai kelas kontrol yang menggunakan metode konvensional. Hasil riset menunjukkan bahwa strategi pembelajaran dan komunikasi kooperatif berpengaruh signifikan terhadap prestasi belajar siswa. Hal ini didukung data yang menunjukkan bahwa prestasi belajar siswa yang dicapai dalam pembelajaran Bahasa Indonesia lebih baik dibandingkan dengan prestasi belajar siswa yang menggunakan strategi pembelajaran konvensional. Kontribusi penelitian ini adalah memberikan wawasan kepada para pendidik mengenai strategi yang lebih baik dalam pembelajaran Bahasa Indonesia untuk siswa.
\end{abstract}

Kata kunci: strategi komunikasi, pembelajaran kooperatif, kuasi eksperimen

\section{Introduction}

It is already well known that communication is everywhere, home, school, office, and mosque; Even communication can touch all aspects of our life (Rachmat, 1985). It implies that almost all human activities are always touched by communication. Communication is an important foundation in the relationship between the communicator and communicant. Giving something to other person means in the context social interaction. (Leila, 243, 2017). The important aspect 
of communication is if someone interferes something or with someone behaves. In communication, a meaning also becomes very important to be interfered by someone who gets information (news) because the meaning which is sent by communicator (receiver) and informant (audience) become subjective, and it is decided by the social context when the information is given and accepted (Bungin, 2006: 21).

Communication is a medium to make relationships between people with others; there is a social relationship because of the existence of communication.In the process communication is a social process to transmitting or convey a feeling or information either in the form of ideas or ideas to influence others.Communication also has an important role in support education. With good communication between one and another then the similarity of meaning to reach the same purpose will be easily achieved.

Education can not run smoothly without the support of communication. Moreover, education only can run only through communication (Jourdan, 1984). In other words, there is no education which is not born by communication. Such circumstances indicate the success of a communication process that takes place between two sides. (Aminullah, Puji Lestari, dkk, 274-275, 2015).

Communication in éducation is one of an important element, it plays an important role in determining the success of education. Communication factor, especially education communication influence the level of education quality achievement. In the implementation of formal education (education through school), the role of communication is very prominent, especially in the process of teaching and learning, both intra-persona communication and interpersonal. The term of education-communication is still not familiar to the people who interest in communication studies. This field is not as popular as political communication, business communication, marketing communications, organizational communication, intercultural communication and others. Though scholarly communication has an important position both in the context of study in the realm of science and science education as well as practical skills that can support the education process.

As Pawit M Yusuf (2010: 2) says that scholarly communication is a process and communication activity which is designed specifically for the purpose to increase added value for the target, which is actually in many things to increase the literacy in many technological areas, communication, and information. The other learning process nowadays is less effort in developing thinking ability which is lead the students to understand the social problem. One of researcher said that social condition is one of the basic motifs in behaving (Leila, 2017: 254).

According to UU RI Number $20 \mathrm{Th}$ 2003 about sidings, (article) 1 paragraph (1) that education is a conscious and planned effort to create learning atmosphere and learning process so that learners actively develop their potential to have spiritual power, self-control, personality, intelligence, and skills which are needed by himself, society, nation, and country. The fact is 
almost 80 percent of teachers 'and lecturers' activities in the classroom are verbal and non-verbal communication activities. Therefore, the bad results that accepted by the students are actually not because of the teacher or lecturer, but because of the bad communication methods in teaching. Thus education activities cannot run smoothly without communication; education can only run through communication. One of communication method that can be used in teaching is cooperative learning. In this learning model, each student is enabled to learn in groups to help each student's understanding, so that there is an increase of value both in individual and group to get an additional value to the increasing of individual values of each group.

Learning with small group teaching enables students to learn more creatively and develop leadership traits in students and can meet students' needs optimally. Ibrahim (2000: 17) states "The results show that cooperative learning has a positive impact on a low student learning results." This is due to the cooperative learning take advantage of students tend to make interaction. Cooperative learning model emphasizes on joint learning exercises or learning by forming a team of 4-5 students who focus more on the sharing of tasks that help each other in learning to complete the task given by the teacher. Thus, each team member is expected to complete the subject matter in which case the student can complete the task given by the teacher. This is in line with the research conclusions from Leila (2017:254) which is said that coaching and mentoring is an important part that can not be ignored, because when the two things are loosened then the social capital, the resources that the community already possesses is likely to have no more valuable value because of the declining motivation of the community.

Variations of learning to overcome the difficulties of learning Indonesia Language for students is needed. One of the variations of learning that can be done is learning model Cooperative Learning (CL). Theoretically, the model of Cooperative Learning (CL) has its advantages to be applied in learning Bahasa Indonesia compared with conventional learning model.

Based on the above, there are needs to be alternative learning that can bridge the problem so that the results of the teaching and learning process objectives are achieved. Based on the background, the writer is interested to conduct research, about "Learning Communication Strategy by Using Cooperative Learning Model in Teaching Indonesia Language in Class VIII Junior High School, Bayongbong, Garut Cooperative Learning Model: Theoretical Base

Cooperative learning derived from the word Cooperative which means doing something together by helping each other as a group or a team. Slavin (Isjoni, 2010: 15) said that Cooperative learning is a learning model which is learning and working systems in small groups of 4-6 people are collaborative to stimulate students to be more passionate about learning.

The cooperative learning model is a learning model that helps students develop 
their understanding and attitude according to real life in society. So by working together with members of the group will increase motivation, productivity, and acquisition of learning.

The cooperative learning model is also a teaching model where students learn in small group groups that have different levels of ability. In completing group assignments, each member of the school cooperates and helps each other to understand learning material. Slavin, R.E. (1992), said that; "Cooperative learning is a successful teaching strategy in which small teams, each with students of different levels of ability, use a variety of learning activities to improve their understanding of a subject. Each member of a team is responsible not only for learning what is taught but also for helping teammates learn, thus creating an atmosphere of achievement. Students work through the assignment until all group members successfully understand and complete it".

Each team member is responsible not only for learning, what is taught, but also for helping other learners, thus creating an atmosphere of learning attainment. Students work through duties until all members of the group manage to understand and to complete it.

The cooperative learning model is developed based on constructivist cooperative learning theory. This is seen in from one of Vygotsky's theories that emphasis on the sociocultural nature of Vygotsky's learning that the higher mental phase arises in conversation or cooperation between individuals before the higher mental functions are absorbed in the individual. The cooperative learning model is very different from direct teaching model. Sugandi (2002: 14) suggests that cooperative learning is known as learning in groups. But cooperative learning is more than just group learning or group work because in cooperative learning there is a task that enables open interaction and effective interdependence relationships among group members.

The cooperative learning model is developed to achieve academic learning outcomes; cooperative learning model is also effective to develop students' social skills. Some experts argue that this model is superior in helping students to understand difficult concepts. The developers of this model have been demonstrated that the cooperative reward structure model has been able to increase students' appraisal of academic learning, and changes in norms relating to learning outcomes. In the case, the cultural norms of young people do not like students who want to be academically bumped.

Robert Slavin and other experts have sought to change this norm through the use of cooperative learning. So another important goal of cooperative learning is to teach students the skills of cooperation and collaboration. This skill is very important to have in a society where there are so much work of adults is mostly done in interdependent organizations and where societies are culturally diverse. Meanwhile, many young people and adults still lack social skills. This situation is evidenced by such a small clash between individuals that it can lead to violence or how often people express dissatisfaction when asked to work in a cooperative situation. 
Also, to change the norms which are associated with learning outcomes, cooperative learning can provide benefits for both lower and group students on joint work to complete academic task assignments, upper group students will become tutors for lower group students, thus obtaining special assistance from peers, Which has the same orientation and language. In this tutorial process, the upper group of students will increase their academic ability because giving tutors requires deeper thinking about the relation of ideas to ideas within a particular material.

In cooperative learning not only learn the material only. But students also have to learn special skills called cooperative skills. This cooperative skill works to smooth relationships, work, and tasks. The role of working relationships can be built to develop communication among group members while the role of the task is done by dividing the tasks among group members during the activity.

The basic cooperative skills include: (a) using agreements; (b) appreciate contributions; (c) take turns and share assignments; (d) be in a group; (e) is in the gas; (f) encouraging participation; (g) invite others to speak; (h) finish the task on time; and (i) respect for individual differences.

Intermediate level cooperative skills, including (a) indicating reward and sympathy; (b) express disagreement in an acceptable manner; (c) listen actively; (d) ask questions; (e) make a summary; (f) interpreting; (g) organize and organize; (h) accept, responsibility of ja-wab; (i) reduce tension
Advanced level cooperative skills, including (a) elaborating; (b) checking carefully; (C) asking the truth; (D) setting goals; (E) compromising.

Meanwhile, according to Stahl (Solihatin and Raharjo, 2007: 5), "Cooperative learning model puts students as part of a system of cooperation in achieving an optimal outcome in learning." Referring to the above statement, the authors can conclude that fundamentally cooperative learning model is a model of learning in which students can learn, cooperate and interact with fellow students, to achieve optimal learning objectives.

Cooperative Learning model consists of six stages, namely: The first stage starts from the teacher conveys the learning objectives and motivates students to learn. The goal is that students understand the purpose of learning to be achieved, so clear the target or target learning. Also, classroom teachers motivate students to learn that they are ready to perform various activities. The second stage, presenting information by providing reading materials or teachers presents demonstrations.

The third stage, grouping students in study groups. The teacher explains to students how to form learning groups and helps each group to transition efficiently. The fourth stage, guide group work, and study. The teacher guides the student group while the students do the tasks in the group. The fifth stage, doing an evaluation. The teacher evaluates all the material that the student has learned. The group then prefers the work. The ultimate stage, rewarding. The teacher rewards group efforts or individual efforts within the group. 
Most cognitive theorists believe that humans derive information received through five stages; First sensory input is the occurrence of the sensing process to the stimuli that exist in the environment. Not all incentives will be absorbed by the sensing device. Only the stimuli that fit the needs of the process. Both central processing. At this stage occurs the process of giving meaning (perception) to incoming information. Giving meaning is a complex process and involves many internal and external factors. The third information storage is the stage of storing information that goes into the warehouse of human memory. There are two types of memory warehouse that is short-term memory (short-term memory) and long-term memory (longterm memory). The fourth information retrieval is calling back information that is led in the memory warehouse. The fifth utilization, that is, how we call and transform information will influence the nonverbal behavior and discussion that will take place. (Griffin,2003: 112-114).

This theory has much to do with attitude, the change of attitude and persuasion. Everyone has the same understanding of the premise of consistency, where everyone likes consistency more than inconsistencies. Consistency is a central principle in cognitive processes and attitude changes that are the result of information that destroys balance (Littlejohn, 1996: 141). One of the theories of cognitive consistency is cognitive dissonance theory. The term cognitive dissonance is derived from the theory put forward by Leon Festinger, which means incompatibility between cognition as an attitude aspect with the behavior that occurs in a person. People who will experience dissonance will try to find excuses to repeat the dissonance (Rohim: 2009)

In general, if we see people who behave in a consistent manner with what they have known, then we hope the same as what we imagine. But in fact, it turns out that people are often not consistent with his behavior. Every student imagines what they want to gain in the learning process according to their shadows and expectations. Then if the learning process does not match, then he will experience cognitive dissonance. In other words, the process of interaction and communication will not run effectively so that the learning process will be disrupted.

Rohim (2009: 74) says that the theory of social exchange views the interpersonal relationship as a trade transaction. People relate to others for wishing something that fulfills their needs. As an example, we can take from that statement, when someone (just " $A$ ") is rich but suffers broken home that befriends the " $\mathrm{B}$ " who is very poor. They look very familiar; the $\mathrm{B}$ is always there wherever the $\mathrm{A}$ is located and vice versa. In this example B is familiar with A, since A always gives him help in material form, and B reply all in attention to A, so that between the two can be regarded as two related people for wishing to fulfill his needs. In other words, A befriends and close to the $\mathrm{B}$ to get affection, attention that he never got from his parents. While the $\mathrm{B}$ is friendly and familiar with A to take daily needs such as clothing, food, the board to survive in conditions of poverty it. 
Thibault and Kelly the two experts of the theorymodelconcludethat theirsocialexchange is "that every individual will voluntarily enter and live in a social relationship whenever the relationship is satisfactory regarding rewards, cost, profit and comparison rates." From the above assumptions, it can be interpreted that the process of communication and interaction of learning that occurs in the classroom cannot be separated from the effective relationship between students and teachers as a social exchange process. As a consequence that the relationship of interaction can be positive or lead to something negative, as it is obtained by someone from a relationship. The consequence is a reward of social acceptance.

Also, the ability of a communicator is very important to the effectiveness of communication. Teachers are communicators who are responsible for the effectiveness of the communication process in the classroom. Because a teacher should have the good credibility to ensure good and quality learning in the classroom. As to how credibility according to Aristotle, can be obtained if a communicator has ethos, pathos, and logos. Ethos is the power the speaker has of his character so his utterances can be believed. Pathos is the power that a speaker has in controlling the emotions of his audience, while logos is the power that communicators possess through their argumentation.

James Mc-Croskey (in Rohim:2009) Explains that the credibility of a communicator can be derived from competence, attitude, intention, personality. Competence is the mastery possessed by a communicator on the problem he/she has discussed. A doctor, for example, talks more about health than a Civil Engineer, and so on the other side. Attitude shows the person of the communicator, whether he is tough or tolerant in principle. The purpose is to show whether the things communicated by a communicator have good intentions or not. Personality shows whether the speaker has a warm and friendly person. While the dynamics indicate whether the thing that is presented is interesting or in fact it is boring communicant.

According to the form of credibility can be divided into three kinds, (1) Initial Credibility, that is the credibility that the communicator gains before the communication process takes place, for example a well-known speaker can bring a lot of listeners, or the writings of a famous Professor DeddyMulyana, JalaluddinRakhmat will be easily published in newspapers even though the editor has not read them; (2) Derived Credibility, Namely, the credibility that a person acquires during communication. For example, a SusiloBambangYudhoyono earned a pat on the part of the community because his speech gave him the pleasure of his listeners (the public); (3) Terminal Credibility, That is, the credibility that a communicator receives after the listener or reader follows his review. A communicator who wishes to gain credibility needs to have in-depth knowledge, extensive experience, as well as respectable powers and social status.

The interactional model developed by Wilbur Schram (1954) which emphasizes the process of two-way communication between the communicators. In other words, the communication goes both ways: from the sender to the recipient and from the 
recipient to the sender. This circular process indicates that communication always takes place. An interactional view illustrates that a person can be a sender or a recipient in an interaction, but not both.

The important elements in this model are feedback or responses to a message. Feedback can be either verbal or nonverbal, intentional or not. Feedback greatly helps communicators to see if their message has been delivered or not and to what extent achievement of meaning has occurred. In the interactional model the backlash occurs after the message is received, not while the message is being sent, there is also the most important element or another part in the interactional communication concept characterized by the field of experience of a person, culture or ancestry that can influence The ability to communicate with others. Each communication participant brings a unique and distinctive experience in every communication behavior that can affect the communication that occurs. Schematically can be seen in the picture of the following interactional model:

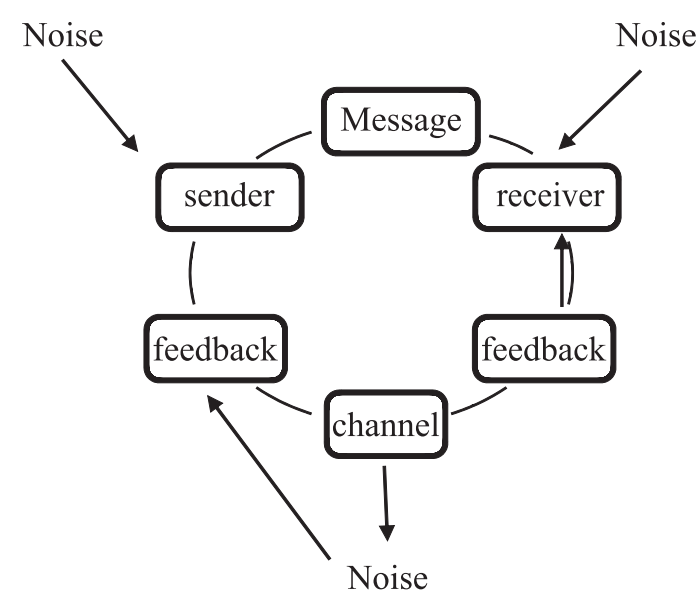

Picture 1. Interactional Communication Model (Sources: West Turner 2007:12)
The purpose of this research is to test the student's learning achievement in class VIII SMPN 1 Bayongbong by using interactional education communication strategy in learning Indonesia Language by using "cooperative learning (CL)" model which is done by the teacher in class. "Cooperative learning" model is a learning model which emphasizes that every learning process, students are active in build their knowledge (student-centered).

\section{Research Method}

The method used in this study is the experimental method, which is a research method that aims to assess the effect of a treatment (treatment) on the behavior of a particular population or test the hypothesis of the presence or absence of the influence of treatment when compared with other measures. In other words, the experimental method aims to examine the effect of a particular treatment on the symptoms of a particular group compared with other groups using different treatments.

In practice, experimental research is divided into three which are the nation experiment, quasi-experiment and pure experiment (Sukamto: 1995). In this research used quasi experimental research (Quasi Eksperimen). A quasi-experiment is a type of comparison that compares the effect of giving a treatment (Treatment) on an object (intervention class) and looking at the effect of its treatment. Quasi experimental research is a study intended to determine whether there is a result of "something" imposed on the subject under study. The trick is to compare one or more comparison groups that receive treatment. 
The design of this study used two groups of the same population. Group, I was treated and group II without treatment. The treated group is called an intervention class and the group without treatment is called a nonintervention class. Classes of intervention and non-intervention classes are equally assessed for performance from preparation to end.

The experimental design which is used in this study is treatment by matched group designs, is the most used design of researchers to test the efficacy of a learning method than other methods. The data for preparation in the design of this experiment will be obtained from the pretest results to the students who will be used as research subjects.

The form of experimental design which is used in this study is nonequivalent control group design. The use of this experimental design form is based on the consideration that research is assumed to control all external variables that may influence the course of the experiment. Besides that, the determination of the experimental group and the control group was determined purposively. The research method or design is described as follows:

$\begin{array}{llcc}\text { Group } & \text { Pretest } & \text { Treatment } & \text { Posttest } \\ \text { A } & \mathrm{O}_{1} & \mathrm{O} & \mathrm{O}_{2} \\ \text { B } & \mathrm{O}_{3} & \mathrm{O}_{4}\end{array}$

$\mathrm{A}=$ Experimental Group treated

$\mathrm{B}=$ Control Group

$\mathrm{O}_{1}=$ Preliminary test before treatment is given to the experimental group

$\mathrm{O}_{2}=$ The final test after treatment is given to the experimental group

$\mathrm{X}=$ Treatment using Cooperative Learning learning

Chart 2. Nonequivalent Group Pretest-Postest Design (Saifuddin Azwar, 1997: 117)
Based on the above designs both groups are an equally assessed performance that aims to determine the competence of each.

The population is a generalization region consisting of objects/subjects that have certain qualities and characteristics set by the researchers to be studied and then made conclusions (Sugiyono, 2007: 61). Meanwhile, according to SaifudinAzwar (1997: 77) population is a subject group to be subjected to the generalization of research results. The population in this study is all students of class VIII SMP Bayongbong Garut consisting of 3 classes with the number of 100 students. In determining the population, it is done with the assumption that class VIII A needs to get this treatment, so it can be concluded that the definition of population is the whole that will be investigated in a place.

According to Sugino (2007: 62) sample is part of the number and characteristics possessed by the population. Saifudin Azwar (1997: 79) sample is part of the population, whereas according to Sukardi (2008: 54) Sample is a portion of the population number selected for the data source. Based on the two opinions can be concluded that the definition of the sample is a member of the population that will be studied in the study.

Sampling or determination for the intervention class and non-intervention class from 3 classes is done by the sampling of probability technique, in the form of random sampling is a random sampling technique (Sugiyono, 2007: 64). A random determination was made with the intention that each class has the same opportunity to be sampled in the study, which is randomly classed here. Basically, this part 
explains how the research was done. The subject matter of this section is (1) research design; (2) population and sample (research target); (3) data collection and instrument development techniques; (4) and data analysis techniques. For research using tools and materials, it is necessary to write down the specifications of the tools and materials. The specification of the tool describes the sophistication of the tool used while the material specifications describe the kinds of materials which is used.

To collect research methods, the data technique used is as follows, (1) The test, consisting of two tests, namely pre-test and post-test ; (2) Questionnaire, is a data completion technique that is done by giving a set of questions and written questions to the respondent to be answered. The questionnaire can be a question that is being closed or open. In this study, the researcher uses closed questions or questions that will help respondents to answer quickly, and also facilitate researchers in analyzing data on the entire questionnaire that has been collected. A closed question is a question that expects a short answer or expects the respondent to choose one alternative answer to each question that has been provided ; (3) Observation, is bounded as a deliberate and systematic study of social phenomena and psychic symptoms by doing observation and recording. Furthermore, the purpose of observation is to understand the characteristics and extent of the significance of their interrelationships of human behavioral elements in complex societal phenomena in certain patterns. Therefore, the researcher conducted a direct observation on the students as respondents, with the aim to obtain data influence the use of cooperative learning model to the students' critical thinking ability; (4) Library research (Library research), conducted to obtain secondary data by studying literature, books, notes as a theoretical foundation that will be compared with the problems studied.

\section{Results and Discussion}

The results of hypothesis test data score increase in learning achievement (gain) can be seen in the following table. 1

The results of hypothesis testing data score increase in learning achievement at the level of significance $\alpha=0.95$, obtained $\mathrm{t}$ value $=4.41$. The value is greater than the amount of $\mathrm{t}$ table $=1.67$ for dark $=55$, because the value of $t$ count $>t$ table, then Ho is rejected so take Ha, meaning there is a significant influence of cooperative learning strategies on student achievement.

Based on the observation data conducted during the learning activity takes place on the percentage of students in the experimental class with very good criteria that can be seen in the following table 2.

Based on the observations in the experimental class, the students in the experimental class perform cooperative skills with very good criteria. The results of this

Table 1

Results of Hypothesis Test Data Analysis

\begin{tabular}{|c|c|c|}
\hline \multirow{2}{*}{ Data } & \multicolumn{2}{|c|}{ Hypothesis Test ( $\mathrm{t}$-Test) } \\
\cline { 2 - 3 } The & $\mathrm{t}$ Score & Result \\
Enhance- & & \\
ment of & $\mathrm{T}_{\text {score }}=4,41>\mathrm{t}_{\text {table }}=1,67$ & $\mathrm{H}_{\mathrm{A}}$ accepted \\
Learning & & \\
(gain) & & \\
\hline
\end{tabular}

Source: Researcher Data 2017 
Table 2

The Result of Class Observation Data Analysis Experiment

\begin{tabular}{|c|c|c|c|c|c|c|c|c|c|c|}
\hline \multirow{3}{*}{ Group } & \multicolumn{10}{|c|}{ Cooperative Skill } \\
\hline & \multicolumn{2}{|c|}{ BDT } & \multicolumn{2}{|c|}{ MDA } & \multicolumn{2}{|c|}{ BGDT } & \multicolumn{2}{|c|}{ BTN } & \multicolumn{2}{|c|}{ MPR } \\
\hline & Percent & Criteria & Percent & Criteria & Percent & Criteria & Percent & Criteria & Percent & Criteria \\
\hline $\mathbf{A}$ & $93 \%$ & $\begin{array}{l}\text { very } \\
\text { good }\end{array}$ & $90 \%$ & $\begin{array}{l}\text { very } \\
\text { good }\end{array}$ & $100 \%$ & $\begin{array}{l}\text { very } \\
\text { good }\end{array}$ & $100 \%$ & $\begin{array}{l}\text { very } \\
\text { good }\end{array}$ & $80 \%$ & good \\
\hline B & $100 \%$ & $\begin{array}{l}\text { very } \\
\text { good }\end{array}$ & $100 \%$ & $\begin{array}{l}\text { very } \\
\text { good }\end{array}$ & $90 \%$ & $\begin{array}{l}\text { very } \\
\text { good }\end{array}$ & $100 \%$ & $\begin{array}{l}\text { very } \\
\text { good }\end{array}$ & $80 \%$ & good \\
\hline C & $92 \%$ & $\begin{array}{l}\text { very } \\
\text { good }\end{array}$ & $100 \%$ & $\begin{array}{l}\text { very } \\
\text { good }\end{array}$ & $88 \%$ & $\begin{array}{l}\text { very } \\
\text { good }\end{array}$ & $75 \%$ & good & $100 \%$ & $\begin{array}{l}\text { very } \\
\text { good }\end{array}$ \\
\hline D & $83 \%$ & $\begin{array}{l}\text { very } \\
\text { good }\end{array}$ & $88 \%$ & $\begin{array}{l}\text { very } \\
\text { good }\end{array}$ & $100 \%$ & $\begin{array}{l}\text { very } \\
\text { good }\end{array}$ & $75 \%$ & good & $75 \%$ & good \\
\hline $\mathbf{E}$ & $100 \%$ & $\begin{array}{l}\text { very } \\
\text { good }\end{array}$ & $88 \%$ & $\begin{array}{l}\text { very } \\
\text { good }\end{array}$ & $88 \%$ & $\begin{array}{l}\text { very } \\
\text { good }\end{array}$ & $100 \%$ & $\begin{array}{l}\text { very } \\
\text { good }\end{array}$ & $100 \%$ & $\begin{array}{l}\text { very } \\
\text { good }\end{array}$ \\
\hline F & $92 \%$ & $\begin{array}{l}\text { very } \\
\text { good }\end{array}$ & $100 \%$ & $\begin{array}{l}\text { very } \\
\text { good }\end{array}$ & $100 \%$ & $\begin{array}{l}\text { very } \\
\text { good }\end{array}$ & $75 \%$ & good & $100 \%$ & $\begin{array}{l}\text { very } \\
\text { good }\end{array}$ \\
\hline average & \multicolumn{2}{|c|}{$93,00 \%$} & \multicolumn{2}{|c|}{$94,00 \%$} & \multicolumn{2}{|c|}{$94,00 \%$} & \multicolumn{2}{|c|}{$88,00 \%$} & \multicolumn{2}{|c|}{$89 \%$} \\
\hline $\begin{array}{c}\text { average } \\
\text { observation }\end{array}$ & \multicolumn{10}{|c|}{$92 \%$ (very good) } \\
\hline
\end{tabular}

Source: Researcher Data 2017

Table 3.

The Result of Observation Data Analysis in Control Class

\begin{tabular}{|c|c|c|c|c|c|c|c|c|c|c|}
\hline \multirow{3}{*}{ Group } & \multicolumn{10}{|c|}{ Cooperative Skill } \\
\hline & \multicolumn{2}{|c|}{ BDT } & \multicolumn{2}{|c|}{ MDA } & \multicolumn{2}{|c|}{ BGDT } & \multicolumn{2}{|c|}{ BTN } & \multicolumn{2}{|c|}{ MPR } \\
\hline & Percent & Criteria & Percent & Criteria & Percent & Criteria & Percent & Criteria & Percent & Criteria \\
\hline A & $67 \%$ & $\begin{array}{l}\text { very } \\
\text { good }\end{array}$ & $63 \%$ & $\begin{array}{l}\text { very } \\
\text { good }\end{array}$ & $75 \%$ & good & $63 \%$ & good & $50 \%$ & good \\
\hline B & $63 \%$ & good & $63 \%$ & good & $69 \%$ & $\begin{array}{l}\text { very } \\
\text { good }\end{array}$ & $50 \%$ & good & $50 \%$ & $\begin{array}{l}\text { very } \\
\text { good }\end{array}$ \\
\hline C & $63 \%$ & good & $63 \%$ & good & $63 \%$ & good & $88 \%$ & $\begin{array}{l}\text { very } \\
\text { good }\end{array}$ & $75 \%$ & good \\
\hline D & $67 \%$ & good & $71 \%$ & good & $57 \%$ & good & $57 \%$ & average & $57 \%$ & good \\
\hline average & \multicolumn{2}{|c|}{$65 \%$} & \multicolumn{2}{|c|}{$65 \%$} & \multicolumn{2}{|c|}{$66 \%$} & \multicolumn{2}{|c|}{$65 \%$} & \multicolumn{2}{|c|}{$58 \%$} \\
\hline $\begin{array}{c}\text { average } \\
\text { observation }\end{array}$ & \multicolumn{10}{|c|}{$64 \%$ (good) } \\
\hline
\end{tabular}

Source : Researcher Data 2017

study are intended to provide an understanding of the results obtained research. Based on observations in the control class showed that students in the control class perform cooperative skills with good criteria.

Based on observations in the control class showed that the students in the control class performed cooperative skill activities with good criteria. From the observation data obtained during two days in the experimental class and in the control class, it can be seen the average observation of the experimental class and the control class. The average percentage of students who perform cooperative skills of the experimental class and control class can be seen in the following table 4 . 
Table 4.

The Average of Experiment Class and Control

\begin{tabular}{ccc}
\hline Observation Data & $\begin{array}{c}\text { Experiment Class } \\
\text { (Cooperative Learning Strategy) }\end{array}$ & $\begin{array}{c}\text { Control Class } \\
\text { (Conventional Group Learning Strategy) }\end{array}$ \\
\hline Day 1 & $92 \%$ & $74 \%$ \\
Day 2 & $82 \%$ & $64 \%$ \\
Mean & $87 \%$ & $69 \%$ \\
\hline Criteria & Excellent & Good \\
\hline
\end{tabular}

Source: Researcher Data 2017

The common observation indicates that during the teaching-learning process, students in the experimental class are better in performing aspects of cooperative skills than students in the control class. This is indicated by the percentage of students who perform cooperative skills in the experimental class including very good criteria while the students in the control class include both criteria.

The discussion of the results of this study is intended to provide an understanding of the research results which is obtained. Based on the data analysis of research results, it can be stated things that are concerning with the results of research as follows:

Communication strategy by using cooperative learning model which can be seen from the pretest result, a pre-test score shows students' initial understanding of the which is given with the learning achievements an indicator the increasing of students' ability from the initial ability which is measured through pre-test to the mastery of competence as measured by post-test after the interaction between individuals and individuals with their environment during the learning process. After the process of communication and interaction between individuals (students) with other individuals (students) and individuals (students) with the environment during the learning process. This is by the understanding of learning achievement according to Ibrahim (2003: 3 ) that the learning achievement is a change in behavior in the form of knowledge, skills, attitudes, and information obtained by students after interacting with the environment in an atmosphere or learning conditions.

The students 'initial ability before the start of the learning process shows that the average of students' initial abilities in the experimental class and control classes includes similar criteria. This is proven by the homogeneity test of the variance of pre-test data proves that both classes are homogeneous.

The difference can be seen in the second post-test result of the class which is the research sample is the experimental class using cooperative learning strategy and control class using conventional group learning strategy. Post-test results showed that the average post-test score of students using cooperative learning strategies is higher than the average post-test scores of students using conventional group learning strategies

The difference of post-test score with pre-test shows improvement of student achievement (gain). The average increase in student achievement (gain) in the 
experimental class including high category while the average increase in student achievement class control is the classified category. The average gain is used to prove the proposed hypothesis. Based on the hypothesis test obtained Tscore $>$ Table, meaning cooperative learning strategy has a significant effect on student achievement.

Teachers are communicators who are responsible for the process of communication effectiveness of learning in the classroom. In the process of communication and interaction, teacher as the communicator in the process of learning "cooperative" turned out to provide a significant influence on student achievement. This is because the implementation of the learning process in the classroom using communication strategies with the cooperative learning of students is conditioned into learning groups consisting of four to six members with high academic ability, moderate and low.

The purpose of grouping so that there is communication between students who has high academic ability with students who have low academic ability with the purpose to help other students who have not understood the lessons or students who have less academic ability. The process of interaction and communication can stimulate learning achievement and learning in the classroom, especially in the members of the interacting group. Student interaction in groups with fewer members are proved better, this was supported by observational data indicating that the percentage of students in the experimental class who performed cooperative skills amounted to $87 \%$ including very good criteria while control class was only $69 \%$ including good criterion.
The limitation of the number of members in each group consists of four to six people, and consists of students with different academic abilities causing each student are more concentrate when the learning activities are implemented, and there is teaching by peers. This is consistent with the opinion of Lie (2004: 12) which explains that peer teaching is more efficient than teacher teaching.

It's different conditions with students using conventional group learning strategies. The number of group members consisting of seven to eight people based on the students' wishes caused some students who did not concentrate during the learning activities, the students joked and discussed things outside the subject matter.

As Aderson (in Rohim: 2009) says that situational factors are sometimes referred to as the determinant of attention that is external or attention getter. Stimuli are noticed because they have prominent properties, among others: the movement of the intensity of stimuli, novelty, and repetition.

Giving different strategies in receiving these teaching materials will provide a different experience for students to allow for different learning achievements when compared to ordinary conditioning. The active process between students in a group in seeking answers, expressing opinions and summarizing an answer illustrates that students actively construct or shape the meaning of what they see, hear, feel and experience. This is in accordance with the opinion of Suparno (1997: 49) which suggests that knowledge is built by the students 
themselves, knowledge cannot be transferred directly from teacher to student except with the activeness of students, students actively construct continuously so that there is always a change of concept towards a more detailed concept, complete as well as concepts.

In cooperative learning, each student has the same responsibility to achieve maximum learning achievement. Individual success is the success of the group, as well as the opposite of individual failure, is a group failure. Therefore, each member of the group should have full responsibility for the group. This is in accordance with the basic elements of cooperative learning proposed by Lungdren in Kadir (2000: 19) that, (1) Students should have the perception that they "drown or swim" together; (2) Students have a responsibility to each other students in the group, besides responsibility to itself in learning the material which is faced; (3) Students should have the same goals; (4) Students should share duties and share responsibilities equally among the group members; (5) Students will be given an evaluation or award, which will contribute to the evaluation of all group members.

Based on the above discussions, it is clear that cooperative communication learning strategies have a significant effect on student achievement, this is supported by data showing that student achievement in learning Indonesia Language is better than student achievement using conventional group learning strategy. The effect is caused by the active and equal opportunity for students in expressing opinions and the occurrence of peer teaching so that students are more understand the subject matter.

\section{Conclusion}

Based on the results of analysis of research data can be concluded, that communication in education is one of an importantelement, itplays an important role in determining the success of education. One of the implementations of communication strategies is using cooperative learning model. It is very influential on student learning outcomes in learning Bahasa Indonesia. The learning outcomes of students using conventional learning models and using the way of communicating in one way (linear) in learning Indonesia Language is less showing good improvement, by obtaining an average score of 56.79 from the previous 52.11. The difference in learning outcomes using the cooperative learning model is also significantly different from the conventional learning model. This can be seen from the acquisition of $t$ value $=4.41$. The value is greater than the value of $\mathrm{t}$ table $=1.67 \mathrm{for} \mathrm{dk}=55$, because the value of $\mathrm{t}$ arithmetic $>t$ table, then Ho is rejected so take $\mathrm{Ha}$, meaning there is the significant influence of cooperative learning strategy on student achievement.

However, the development of research with the use of other communication strategies also needs to be done by further researchers, especially communication strategies and approaches with circularcommunication model or the use of research type with a qualitative approach with subjective perspective.

\section{References}

Aminullah, PujiLestari, dan Sigit Tripambudi. (2015). Model Komunikasi Antar budaya Etnik Madura dan Etnik Melayu. Jurnal Aspikom, Volume 2 No.4 hal.274-275, Januari 2015. 
Azwar, Saifudin. (1997). Reliabilitas dan Validitas. Edisi 3. Yogyakarta: Pustaka Pelajar.

Bungin, Burhan. (2006). Analisa Data Penelitian Kualitatif: Pemahaman Filosofis dan Metodologis ke Arah Penguasaan Pola Aplikasi. Jakarta:Raja Grafindo Persada.

Griffin, Emory A., (2004). A First Look at Communication Theory, $5^{\text {th }}$, ed, Printed in Singapore.

Ibrahim, R.(2002). Kurikulum Pembelajaran. Bandung: Jurusan Kurikulum dan Teknologi Pendidikan FIB UPI.

Ibrahim, H.M. (2000). Pembelajaran Kooperatif. Surabaya: UniversitasNegeri Surabaya

Lie, Anita. (2003). Cooperative Learning (Mempraktikkan Cooperative Learning di Ruang-ruang Kelas). Jakarta: Grasindo

Mona, Leila Gainem. (2017). Pemberdayaan Perempuan Miskin Kota Melalui Pendidikan. Jurnal Aspikom, Volume No.2, hal.239-255, Januari 2017

Rahmat, Jalaluddin. (1985). Metode Penelitian Komunikasi. Bandung: Remaja Rosda Karya

Rohim, Syaiful. (2009). TeoriKomunikasi, Perspektif, Ragam, dan Aplikasi. Jakarta: PT. RinekaCipta
Schramm, W. L. (1954). The Process and Effect of Mass Communication. Urbana: University of Illinois Press.

Slavin, R. E. (1995). Cooperative Learning Theory, Research, and Practice. $2^{\text {nd }}$ Ed. London: Allyn and Bacon.

Sugiono. (2010). Metode Penelitian Kuantitatif Kualitatif dan $R \& D$. Bandung: Alfabeta

Sugandi, A.I. (2002). Pembelajaran Pemecahan Masala Matmatika Melalui model Belajar Kooperatif Tope Jigsaw. (Studi Eksperimen terhadap Siswa Kelas Satu SMU Negeri di Tasikmalaya). Tesis PPS UPI: Tidak diterbitkan.

Sukardi. (2004). Metodelogi Penelitian Pendidikan Kompetensi dan Praktiknya. Jakarta : PT Bumi Aksara.

Suparno, Paul, dkk. (2002). Reformasi Pendidikan: Sebuah Rekomendasi. Yogyakarta: Kanisius.

Stephen W. Littlejohn. (1996). Theories of Human Communiation, Wadsworth Publication, New Jersey

UU RI No.20, 2003

Yusuf, Pawit M, (1990), Komunikasi Pendidikandan Komunikasi Intruksional, Remadja Rosdakarya, Bandung. 